\title{
WARFARIN THERAPY IN PATIENTS WITH CORONARY HEART DISEASE AND ATRIAL FIBRILLATION: DRUG INTERACTIONS AND GENETIC SENSITIVITY TO WARFARIN
}

\author{
O. A. PANIBRATIUK, O. A. YAKOVLEVA \\ National Pirogov Memorial Medical University, Vinnytsya, Ukraine; \\ e-mail: olaynauka@gmail.com
}

Received: 26 February 2020; Accepted: 30 June 2020

\begin{abstract}
In this research work we examined the effect of various factors on the efficacy and safety of warfarin pharmacotherapy. Particular emphasis was placed on drug interaction in the standardized treatment of patients with coronary heart disease and atrial fibrillation. Since the administration of such drugs as digoxin and statins with warfarin leads to an increase in the blood level of all three drugs (they interact at the level of P-glycoprotein) and warfarin has a narrow therapeutic window, the risk of hemorrhagic complications is increased. For the first time in patients of the Podillya region of Ukraine, the genetic polymorphism of cytochrome CYP2C9 was determined, which is associated with the slow withdrawal of anticoagulant from the bloodstream and the possible risk of bleeding. For safe pharmacotherapy, patients were given significantly different doses of warfarin in all comparison groups, according to the International Normalized Ratio (INR). For example, in the group with a CYP2C9 mutation present, the dose was $3.08 \pm 0.25 \mathrm{mg}$ versus $4.15 \pm 0.22 \mathrm{mg}$ in the non-mutation group $(P=0.008)$. In addition, in patients with genetic polymorphism of detoxification enzymes, significantly more bleeding events (light or clinically significant; critical organ bleeding) were observed, but among these patients bleeding occurred at an INR of 2.6 (despite the recommendations of the European Society of Cardiology, that the INR can be maintained within 2.0-3.0). Therefore, patients with CYP2C9 mutations require a personalized approach and control of the INR in a safer range (2.0 to 2.5) and consideration of drug interactions.
\end{abstract}

Ke y w o rds: warfarin, genetic polymorphism CYP2C9, slow metabolites, interaction of warfarin, anticoagulant-related bleeding.

\section{Introduction}

Atrial fibrillation (AF) is one of the most common forms of heart rhythm disorders, complicating the course of the underlying disease [1]. AF mortality is 2-2.5 times higher in patients with sinus rhythm. The incidence of systemic thromboembolic complications in patients with AF is 5-7 times higher than in patients with sinus rhythm [2].

Administration of oral anticoagulants - vitamin $\mathrm{K}$ antagonists or direct-acting oral anticoagulants (DOACs) significantly reduces stroke mortality in AF patients, while the level of cardiovascular mortality (for example, due to heart failure or sudden death) remains the same, even in patients receiving treatment for AF in accordance with the principles of evidence-based medicine [3].

Warfarin therapy reduces stroke by two-thirds and deaths by a quarter compared to controls (aspirin or no treatment). Vitamin K antagonists (including warfarin) have been used in many patients worldwide with positive results [3].

However, despite the high prophylactic efficacy of warfarin, its prolonged outpatient use is associated with a number of technical difficulties that often significantly reduce the efficacy and safety of therapy. The extent of the anticoagulant effect of warfarin depends both on adherence to the prescribing rules and on the patient's characteristics. Warfarin has a very narrow therapeutic window [4-6], which

(C) 2020 Panibratiuk O. A., Yakovleva O. A. This is an open-access article distributed under the terms of the Creative Commons Attribution License, which permits unrestricted use, distribution, and reproduction in any medium, provided the original author and source are credited. 
is determined by the International Normalized Ratio (INR) level with a target value in the range of 2.03.0. The INR should be monitored regularly (every 4 weeks), and several times a week for dose selection.

Currently, a large group of DOACs is recommended that includes direct thrombin inhibitor (dagibatran) and direct Xa antagonists (apixaban, rivaroxaban). These DOACs do not have inferior efficacy compared to warfarin and do not require constant monitoring of the coagulation system status. Unfortunately, because of their cost however, they remain inaccessible to the vast majority of patients.

Warfarin activity is influenced by various drugs, the most relevant are the effects of digoxin, amiodarone and statins, which correlate with the life expectancy of patients with coronary heart disease (CHD) and AF. Foods rich in Vitamin K, dietary supplements, and alcohol also have effects [7].

Particular attention should be paid to a more detailed evaluation of the interactions between warfarin and the most prescribed drugs in patients with the permanent or long-term persistent form of fibrillation: $\beta$-blockers used to control the heart rate and due to their insufficient effect, digoxin added for additional heart rate control, and statins used to reduce endothelial dysfunction. Potential interactions should be especially considered for the use of digoxin (as a substrate of P-glycoprotein) and the statins (as both substrates and inhibitors of Pglycoprotein). The most powerful drug interactions are characteristic for the first-generation statins (e.g., lovastatin), and to a lesser extent for the secondgeneration (e.g., simvastatin, atorvastatin) and thirdgeneration statins (e.g., rosuvastatin). Warfarin itself is also a substrate and inhibitor of P-glycoprotein, therefore, there is an increase in the blood concentration of these drugs when they are administered concomitantly with warfarin [8].

In addition, statins are also characterized by interaction with the $\mathrm{R}$ enantiomer of warfarin at the level of CYP3A4. However, the major cytochrome that metabolizes warfarin is CYP2C9, which must be considered when prescribing drugs that interact at this level. In particular, it is relevant for torasemide, as it is often prescribed to such patients for the correction of the manifestations of heart failure and in concomitant hypertension. Both these drugs have a high protein binding rate of $97-99 \%$, so they cannot be administered simultaneously in hypoproteinemia and in combination with other drugs that have high protein binding.
Another important aspect of safe pharmacotherapy is the individual sensitivity to warfarin, which is explained by the presence of CYP2C9 genetic polymorphisms $[9,10]$. The presence of the polymorphic variant CYP2C9*2 (i.e., substitution of the amino acid arginine for cysteine at the 144 position [Arg144Cys]) and CYP2C9*3 (i.e., substitution of the amino acid leucine for isoleucine at the 359 position [Ile359Leu] is associated with slower drug clearance and increased bleeding tendency [11]. Cytochrome isoenzyme gene polymorphism is characterized by a pronounced ethnic specificity [12], which requires more detailed study in different populations. Currently, no such research has been conducted in the Podillya region of Ukraine.

The objective of our study was to evaluate the efficacy and safety of warfarin pharmacotherapy in the complex treatment of CHD and AF, taking into account drug interactions and genetic sensitivity to warfarin.

\section{Materials and Methods}

Patients. The study involved 100 patients with a verified diagnosis of CHD in combination with permanent or the long-term persistent form of AF. The study was non-interventional and had a oneyear follow-up period. The diagnosis of CHD was verified according to medical records and considered retrospective data on myocardial infarction, samples with dosed physical load, Holter electrocardiography monitoring, echocardiography, and coronary angiography in the anamnesis. All patients had grade II A heart failure (classification according to Strazhesky N. D. and Vasilenko V. K., which roughly corresponds to functional class III according to the NYHA [13])

Patients were observed on the basis of the municipal non-profit enterprise: Vinnytsia Regional Clinical Medical Center for Cardiovascular Pathology in Vinnytsia, Ukraine. Ethical approval for the study was obtained from the Bioethics Committee of the National Pirogov Memorial Medical University, Vinnytsya on November 2, 2017 (excerpted from protocol No 9).

Study exclusion criteria. Patients were excluded from the study for any of the following: presence of mechanical heart valves; moderate or severe mitral stenosis; acute myocardial infarction at the time of study inclusion, or a period of less than a year after a heart attack; thrombocytopenia; use of antiplatelet drugs, or drugs that additionally interact at the 
level of CYP2C9; hyperthyroidism, diabetes mellitus at the time of study inclusion; cirrhosis of the liver; hepatitis; portal hypertension; hypoproteinemia; renal impairment (GFR $<15 \mathrm{mmol} / \mathrm{l}$; creatinine $\geq 200 \mu \mathrm{mol} / \mathrm{l}$ ); oncopathology; or tuberculosis.

Patients were divided into 2 groups: the warfarin group $(n=50)$ and the warfarin+digoxin group $(n=50)$ in which digoxin was administered for additional heart rate control. In each group, patients received the following standardized drugs: warfarin, bisoprolol, valsartan, atorvastatin or rosuvastatin, and diuretics. It should be noted that the first-line diuretics are thiazide or thiazide-like diuretics. However-, our patients had stage II A heart failure and the vast majority of patients required torasemide, during decompensation and lack of response to prior treatment with thiazide-like diuretics. The effect of torasemide on this treatment regimen was of great interest to us, as it is also metabolized by CYP2C9.

Clinical research methods. The development of embolism on the CHA2DS2-VASc scale, according to the European version of the AF guidelines, was evaluated [3]. The HAS-BLED scale, designed for bleeding risk assessment, was also employed.

Laboratory tests. The patients underwent the following tests: detailed blood test that included biochemical blood examination of the INR (in dynamics with constant control), liver tests, creatinine phosphokinase, and blood sugar level as well as kidney tests, lipidogram and general urinalysis.

Cardiac and abdominal examinations. Patients underwent electrocardiography, Holter electrocardiogram monitoring, ultrasound of the heart and ultrasound of the abdominal organs and kidneys.

Pharmacogenetic evaluation. The CYP2C9 gene polymorphism was assessed in the patients. The genetic study was performed in the educational-scientific clinical-diagnostic laboratory of polymerase-chain reaction of Vinnitsa National Pirogov Memorial Medical University (certificate of attestation No. 051/15 dated 2 March 2015). The identifications of the Arg144Cys polymorphic alleles of the CYP2C9*2 gene and Ile359Leu of the CYP2C9*3 gene were performed by PCR. Genomic DNA was extracted from peripheral blood mononuclear cells using a Gene Jet Whole Blood Genomic DNA Purification Mini Kit (Thermo Scientific, Carlsbad, CA., USA) according to the manufacturer's instructions. To identify the polymorphic alleles of the Arg144Cys gene CYP2C9*2 and Ile359Leu of the CYP2C9*3 gene, amplification of the respective gene segment was performed by allele-specific PCR (two amplification reactions were performed simultaneously with two pairs of allele-specific primers using reagents by the method of SNP-express-PB (Litech, Moscow, RF). Amplification was performed on an iCycler IQ5 instrument (BioRad, Foster City, CA, USA), with amplification mode: $93{ }^{\circ} \mathrm{C}, 1 \mathrm{~min}$; 35 cycles: $93{ }^{\circ} \mathrm{C}$, $10 \mathrm{~s} ; 64{ }^{\circ} \mathrm{C}, 10 \mathrm{~s} ; 72{ }^{\circ} \mathrm{C}, 20 \mathrm{~s}$.

Statistical analysis. The data were processed using Statistica 12.0 StatSoft software (trial), Statistica 6.1 for Windows (licensed №BXXR901E245722FA, National Pirogov Memorial Medical University, Vinnytsya, Ukraine) according to generally accepted methodology (per the recommendations of O. J. Rebrova, 2006) [15]. The estimation of the correspondence of the genotype distribution to the expected value was performed using the HardyWeinberg equilibrium [16]. Intergroup reliability of the difference in quantitative values was calculated by T-test for independent samples by groups, and percentages by the criterion of $\chi^{2}$.

\section{Results and Discussion}

The age of the 100 patients ranged from 39 to 88 years (mean $66.26 \pm 0.97$ years). According to the World Health Organization (WHO) age distribution: 3 patients (3.0\%) were young (25-44 years old), 20 $(20.0 \%)$ were middle-aged (45-59 years), $56(56.0 \%)$ were elderly (60-74 years) and 21 (21.0\%) were senile (75-90 years). Among them, there were 34 men $(34.0 \%)$ and 66 women $(66.0 \%)$. There were no statistically significant differences in the age or gender of patients in the two groups (Table 1).

When observing this contingent of patients, international recommendations suggest determining the previous risk of thromboembolic complications. The patient groups were homogeneous for risk of thromboembolic complications (CHA2DS2-VASc scale) and for risk of bleeding (HAS-BLED scale) (Table 1).

In this study, we were guided by the recommendations of the European Atherosclerosis Society and European Society of Cardiology for the selection of statin dosage based on the SCORE scale for cardiovascular risk (Table 2). According to the recommendations, only $5 \%(n=5)$ of our patients required maximum doses of statins (atorvastatin $80 \mathrm{mg}$, rosuvastatin $40 \mathrm{mg}$ ). Others required lower doses (atorvastatin: 20-40 mg, rosuvastatin 5-20 mg).

Warfarin doses varied significantly between the two groups (provided that patients had the target 
Ta ble 1. Clinical characteristics of the two patient groups

\begin{tabular}{l|c|c|c}
\hline \multicolumn{1}{c|}{ Characteristic } & $\begin{array}{c}\text { Warfarin group, } \\
(n=50)\end{array}$ & $\begin{array}{c}\text { Warfarin + Digoxin group, } \\
(n=50)\end{array}$ & $P$ \\
\hline Men, number, $(\%)$ & $18(36.0 \%)$ & $16(32.0 \%)$ & 0.67 \\
Women, number, $(\%)$ & $32(64.0 \%)$ & $34(68.0 \%)$ & 0.67 \\
Mean age $( \pm \mathrm{SD})$, years & $66.64 \pm 1.31$ & $65.88 \pm 1.44$ & 0.70 \\
CHA2DS2-VASc scale scores, mean $\pm \mathrm{SD}$ & $3.26 \pm 0.17$ & $2.83 \pm 0.19$ & $>0.05$ \\
HAS-BLED scale scores, mean $\pm \mathrm{SD}$ & $2.04 \pm 0.12$ & $2.02 \pm 0.11$ & $>0.05$ \\
\hline
\end{tabular}

SD - standard deviation

Table 2. Dose selection of statins according to cardiovascular risk*

\begin{tabular}{|c|c|c|}
\hline \multicolumn{3}{|c|}{ Cardiovascular risk } \\
\hline Very High & High & Low or Moderate \\
\hline $\begin{array}{l}\text { Target low-density lipoprotein } \\
\text { cholesterol level: }<1.8 \mathrm{~mol} / 1 \\
(70 \mathrm{mg} / \mathrm{dl}) \text { recommended or } \\
\text { reduction of at least } 50 \%\end{array}$ & $\begin{array}{l}\text { Target low-density lipoprotein } \\
\text { cholesterol level: }<2.6 \mathrm{~mol} / 1 \\
(100 \mathrm{mg} / \mathrm{dl}) \text { recommended } \\
\text { or reduction of at least } 50 \%\end{array}$ & $\begin{array}{c}\text { Target low-density lipoprotein } \\
\text { cholesterol level: }<3.0 \mathrm{~mol} / 1 \\
(<115 \mathrm{mg} / \mathrm{dl}) \text { should be considered }\end{array}$ \\
\hline
\end{tabular}

*Based on SCORE scale

INR). In the warfarin+digoxin group, warfarin doses were significantly lower than those in the warfarin group $(3.36 \pm 0.28 \mathrm{mg}$ versus $4.35 \pm 0.21 \mathrm{mg}$, respectively, $P=0.006$ ), indicating a real effect of digoxin on warfarin blood concentrations due to the drug interaction described above (please see introduction).

A detailed analysis of the incidence of bleeding was conducted (Table 3). There were 44 total cases of bleeding, in which 25 patients had one occurrence, 8 patients had two occurrences and one patient had 3 episodes. When the bleeding was categorized by severity and localization, the cases were mainly light or clinically significant in nature. Subject to the INR in the target range more than $60 \%$ of the time and receiving the selected doses of warfarin, the level of bleeding did not differ significantly between the two groups.

This study was the first determination of the prevalence of genetic polymorphisms of cytochrome 2C9 in patients from the Podillya region of Ukraine (Table 4). The vast majority of patients did not have altered alleles (C/C genotype). However, $21 \%$ were carriers of the CYP2C $9 * 2$ mutant allele $(\mathrm{C} / \mathrm{T}$ or $\mathrm{T} / \mathrm{T})$, and $10 \%$ had the CYP2C9*3 mutant allele $(\mathrm{C} / \mathrm{T}$ or $\mathrm{T} / \mathrm{T}$ ), which are associated with an increased risk of hemorrhagic complications. The presence of an altered allele in heterozygous form $(\mathrm{C} / \mathrm{T})$ increases the risk of potential complications by $50 \%$ (since genetic information can still be read from the normal allele). In homozygous form ( $\mathrm{T} / \mathrm{T})$, genotypes with mutant alleles have slower drug clearance properties.

The frequency distribution of genotypes of the CYP2C9 polymorphic variants corresponded to Hardy-Weinberg equilibrium. This finding indicates representative sampling and correct genotyping. The distribution of genes in the groups did not differ significantly, thus the groups can be considered homogeneous, which is an important aspect for their further comparison (Fig. 1).

Genetic polymorphism of detoxification enzymes is undoubtedly influenced by the results of drug interactions. Confirmation of this position was a significant increase in the number of bleeding occurrences in patients with genetic mutations CYP2C9*2 and CYP2C9*3 (both light and clinically significant bleeding; critical organ bleeding). Particularly noticeable effects were observed for homozygous carriers of the mutant alleles. These patients required a significantly lower dose of warfarin to achieve the target value of the INR (2.0-3.0 for patients with AF, according to the recommendations of the European Society of Cardiology), as they are characterized as slow metabolizers, leading to an increase in the blood concentration of warfarin. However, bleeding in patients with a detected genetic polymorphism was observed at an INR 
Table 3. Hemorrhagic complications in the two groups

\begin{tabular}{l|c|c|c}
\hline \multicolumn{1}{c|}{ Hemorrhagic complication } & $\begin{array}{c}\text { Warfarin group, } \\
(n=50)\end{array}$ & $\begin{array}{c}\text { Warfarin + Digoxin } \\
\text { group, }(n=50)\end{array}$ & $P$ \\
\hline All bleeding cases & $18(36.0 \%)$ & $26(52.0 \%)$ & 0.11 \\
Massive bleeding & $0(0)$ & $1(2.0 \%)$ & 0.31 \\
Clinically significant bleeding & $8(16.0 \%)$ & $10(20.0 \%)$ & 0.60 \\
Light bleeding & $10(20.0 \%)$ & $13(26.0 \%)$ & 0.47 \\
Critical organ bleeding & $1(2.0 \%)$ & $2(4.0 \%)$ & 0.56 \\
Gastrointestinal bleeding & $1(2.0 \%)$ & $1(2.0 \%)$ & 1.00 \\
Ischemic stroke & $1(2.0 \%)$ & $2(4.0 \%)$ & 0.56 \\
INR in target range $>60 \%$ of the time & $36(72.0 \%)$ & $31(62.0 \%)$ & 0.29 \\
Frequency of hospitalization due to bleeding & $6(12.0 \%)$ & $8(16.0 \%)$ & 0.60 \\
Frequency of hospitalization due & & & \\
to ischemic complications & $1(2.0 \%)$ & $2(4.0 \%)$ & 0.56 \\
Number of deaths & $0(0)$ & $1(2.0 \%)$ & 0.31 \\
\hline
\end{tabular}

Table 4. Frequency of genotypes and Hardy-Weinberg equilibrium $(n=100)$

\begin{tabular}{l|c|c|c}
\hline Genotype & Structure Frequency, $\%$ & Genotype Frequency & Hardy-Weinberg Equilibrium \\
\hline CYP2C ${ }^{*} 2$ & & & \\
$\mathrm{C} / \mathrm{C}$ & 79 & 0.79 & $79 / 0.845$ \\
$\mathrm{C} / \mathrm{T}$ & 11 & 0.11 & $11 / 0.262$ \\
$\mathrm{~T} / \mathrm{T}$ & 10 & 0.10 & $10 / 0.155$ \\
$\mathrm{CYP} 2 C 9 * 3$ & & & \\
$\mathrm{C} / \mathrm{C}$ & 90 & 0.9 & $91 / 0.893$ \\
$\mathrm{C} / \mathrm{T}$ & 9 & 0.09 & $9 / 0.1039$ \\
$\mathrm{~T} / \mathrm{T}$ & 1 & 0.01 & $1 / 0.0001$ \\
\hline
\end{tabular}

level of 2.6 and above. Therefore, it is important for such patients to have an individual approach and to control the INR in a narrower range (2.0 to 2.5 ), which will increase the safety of pharmacotherapy (Table 5). At the time of the study, the INR (in these patients) was in the new target range of 2.0 to 2.5 for more than $80 \%$ of the time during the one-year follow-up period, during which time both bleeding and thrombotic complications were not observed in this group. The detected mutation frequency reached $30 \%$, with the absence of the mutation at $-70 \%$.

At the same time, in addition to influencing the incidence of adverse drug reactions (bleeding), the genetic polymorphism of the cytochrome provides correction of dose regimens of anticoagulant administration. Thus, it was found that in the presence of mutations, the needed safe dose of warfarin was correspondingly $25.8 \%$ lower than in the absence of mutations $(3.08 \pm 0.25 \mathrm{mg}$ versus $4.15 \pm 0.22 \mathrm{mg}$, respectively, $P=0.008$ ).

Despite the fact that patient groups were generally homogeneous in age, at the same time it was observed that in patients with genetic mutations the risks of hemorrhagic complications were observed 5 years earlier than in patients without them $(62.77 \pm 1.90$ years versus $67.76 \pm 1.1$ years, respectively, $P=0.07$ ).

It is quite challenging to trace the real genetic spectrum of the Ukrainian population. Over the last millennium, there have been attempts to conquer the territories around Kievan Rus, and the numerous victories of the invaders have brought considerable diversity to the gene pool. It may include components of the Mongoloid race (XIII century influence 
A

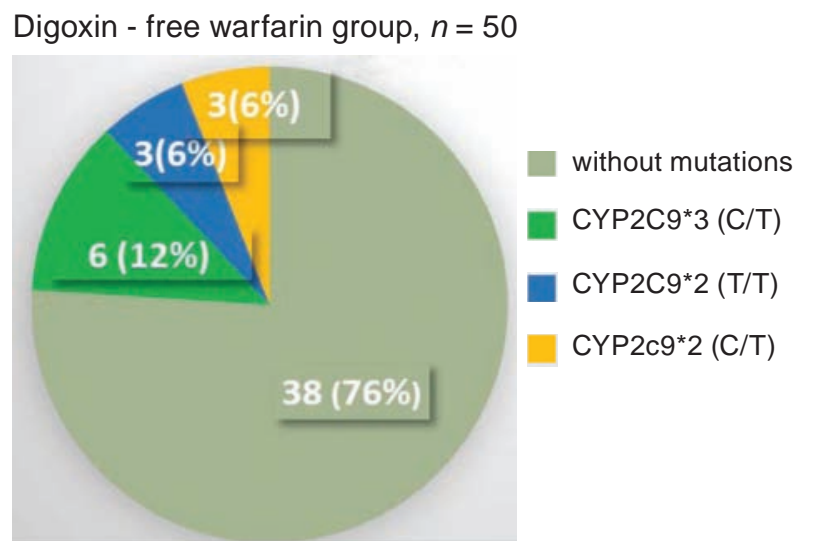

B

Group combining warfarin with digoxin, $n=50$

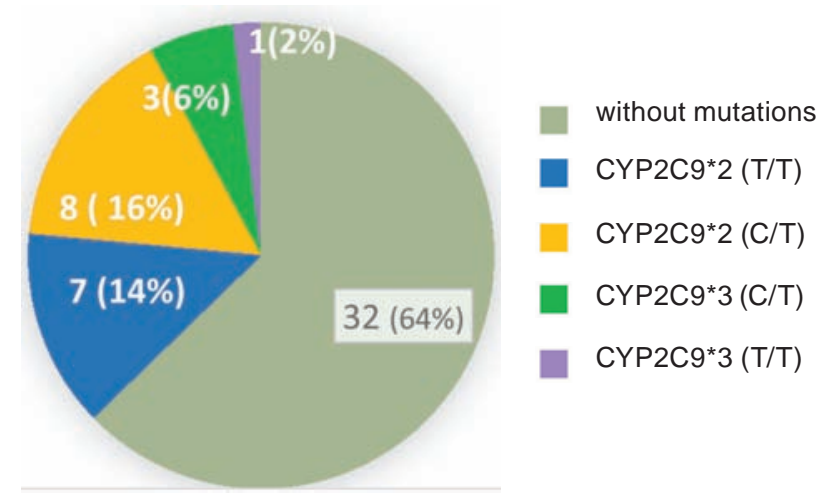

Fig. 1. Genetic characteristics of the (A) warfarin group $(n=50)$ and $(\mathbf{B})$ warfarin + digoxin group $(n=50)$, $P>0.05$

Table 5. The dependence of the extent of bleeding on the presence of the mutations $C Y P 2 C 9 * 2$ and CYP2C9*3

\begin{tabular}{l|c|c|c}
\hline \multicolumn{1}{c|}{ Hemorrhagic complication } & $\begin{array}{c}\text { Gene mutations } \\
\text { present, }(n=30)\end{array}$ & $\begin{array}{c}\text { Gene mutations } \\
\text { absent, }(n=70)\end{array}$ & $P$ \\
\hline Men, number (\%) & $11(36.7 \%)$ & $23(32.9 \%)$ & 0.71 \\
Women, number (\%) & $19(63.3 \%)$ & $47(67.1 \%)$ & 0.71 \\
All bleeding cases & $34(113.3 \%)$ & $10(14.3 \%)$ & $<\mathbf{0 . 0 0 0 1}$ \\
Massive bleeding & $1(3.3 \%)$ & $0(0)$ & 0.12 \\
Clinically significant bleeding & $13(43.3 \%)$ & $5(7.1 \%)$ & $<\mathbf{0 . 0 0 0 1}$ \\
Light bleeding & $19(63.3 \%)$ & $4(5.7 \%)$ & $<\mathbf{0 . 0 0 0 1}$ \\
Critical organ bleeding & $3(10.0 \%)$ & $0(0)$ & 0.007 \\
Gastrointestinal bleeding & $1(3.3 \%)$ & $1(1.4 \%)$ & 0.53 \\
Ischemic stroke & $2(6.7 \%)$ & $2(2.9 \%)$ & 0.37 \\
Frequency of hospitalization due to bleeding & $9(30.0 \%)$ & $3(4.2 \%)$ & $<\mathbf{0 . 0 0 0 1}$ \\
Frequency of hospitalization due & & & \\
to ischemic complications & $2(6.7 \%)$ & $2(2.9 \%)$ & 0.37 \\
*Number of deaths & 1 & 0 & 0.12 \\
\hline
\end{tabular}

*This complication was assessed as an acute cerebrovascular accident of mixed genesis, according to spiral computed tomography. Massive cerebral hemorrhages were observed and there was ischemia in the middle cerebral artery. The patient was an elderly woman with INR=1.6 on the day of death. This case again emphasizes that the risks of both thromboembolic and hemorrhagic complications in patients of this age group are significant. Patients with genetic mutations need special management

of the Golden Horde) and northern tribes (Mordovian-Vladimir-Suzdal). Lithuanian rule from the 1360s also had a significant influence, as did migrations in the southern regions in the XV-XIV centuries. Therefore, scientific interest in a certain limited area, namely the Podillya region of Ukraine, may have its own features, little known in genetic analysis.
Comparison of CYP2C9*2 and CYP2C9*3 polymorphisms in different ethnic groups [16-20] and in the Podillya region of Ukraine are shown in Fig. 2. Some alleles are extremely rare $(<1 \%$ prevalence) in some ethnic groups, but they can be found quite often in others. The most common mutant alleles of CYP2C9*2 are found in Europeans (Czech 

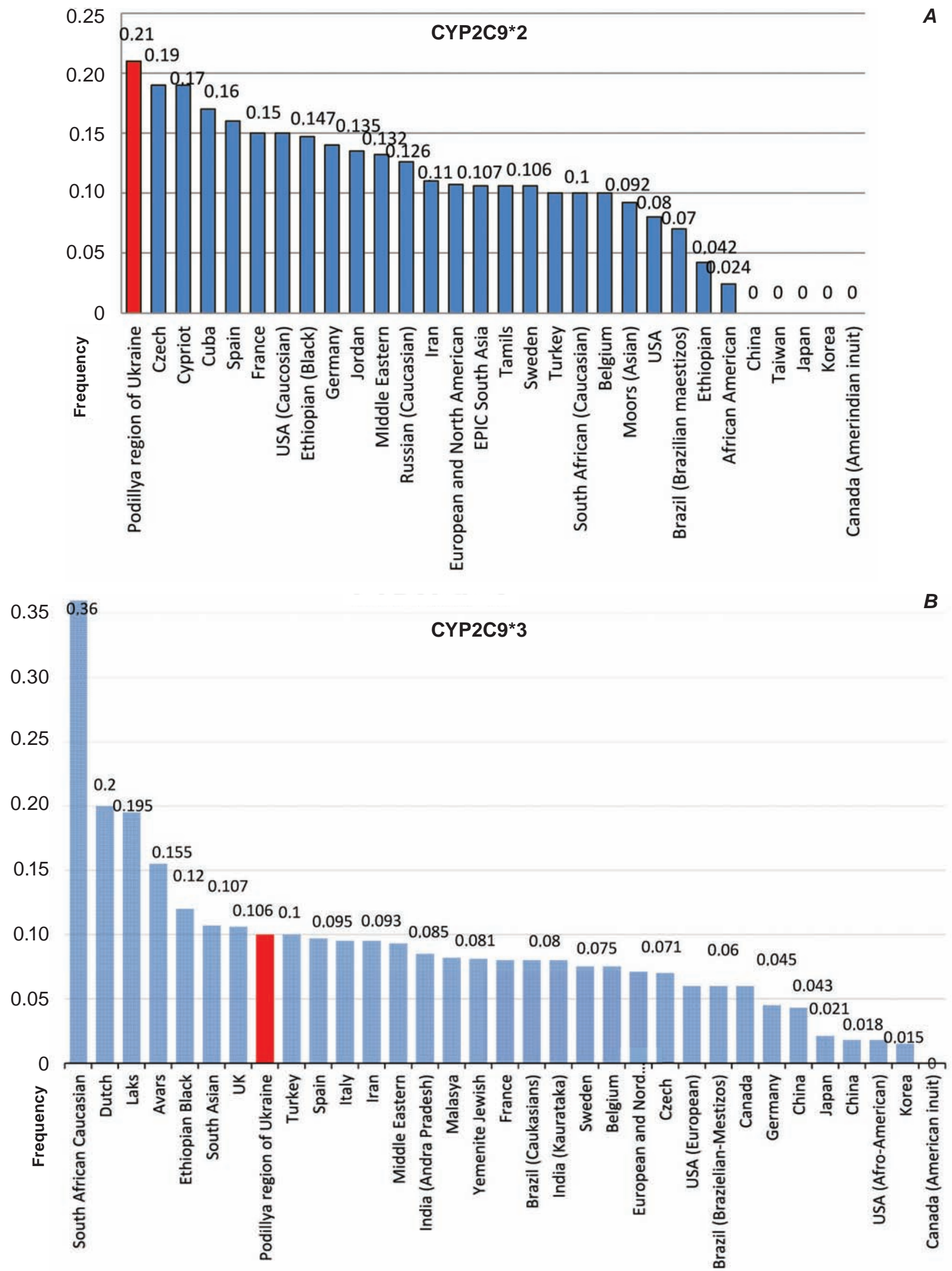

Fig. 2. Comparison of (A) CYP2C $9 * 2$ and (B) CYP2C $9 * 3$ polymorphisms in different ethnic groups and in the Podillya region of Ukraine [16-20] 
Republic, Spain, France). There are almost no allele data in the Orient (China, Taiwan, Japan). The altered alleles of CYP2C $9 * 3$ are most common in Europeans of South Africa, Dutch, Laks, and South Asians. Understanding the presence of altered alleles in the genotype is very important, because in the presence of one altered allele, the necessary dose of warfarin may be lower by $30 \%$, and in individuals with a homozygous form of the mutation by $70 \%$ less. This should be taken into account in clinical practice, as it will allow for safer pharmacotherapy.

Thus, it is obvious that every third patient receiving warfarin and characterized by the presence of the CYP2C9*2 or CYP2C9*3 mutant allele needs special attention given the risk of possible bleeding and the need for careful treatment with anticoagulation dosage regimens. Genetic testing for patients undergoing anticoagulation therapy (in the treatment of vitamin $\mathrm{K}$ antagonists) should become more of a reality in daily medical practice.

Conflict of interest. Authors have completed the Unified Conflicts of Interest form at http://ukrbiochemjournal.org/wp-content/uploads/2018/12/coi disclosure.pdf and declare no conflict of interest.

\section{ТЕРАПІЯ ВАРФАРИНОМ У ПАЦІЕНТІВ 3 ІШЕМІЧНОЮ ХВОРОБОЮ СЕРЦЯ ТА ФІБРИЛЯЩІЮЮ ПЕРЕДСЕРДЬ: ЛІКАРСЬКІ ВЗАЕМОДІЇ ТА ГЕНЕТИЧНА ЧУТЛИВІСТЬ ДО ВАРФАРИНУ}

\section{О. А. Панібратюк, О. О. Яковлева}

\author{
Вінницький національний медичний \\ університет ім. М. І. Пирогова, Україна; \\ e-mail: olaynauka@gmail.com
}

У даному дослідженні вивчався вплив різних факторів на ефективність та безпеку фармакотерапії варфарином. Особливий акцент було зроблено на взаємодію лікарських засобів при стандартизованому лікуванні пацієнтів 3 ішемічною хворобою серця та фібриляцією передсердь. Оскільки призначення таких препаратів як дигоксину та статинів на тлі варфарину призводить до збільшення в крові всіх трьох препаратів (взаємодіють між собою на рівні Р - глікопротеїну), а варфарин має вузьке терапевтичне вікно - підвищуються ризики геморагічних ускладнень. Вперше у пацієнтів Подільського регіону України визначався генетичний поліморфізм СУР2C9, наявність мутантних алелей якого асоціюється 3 повільним виведенням антикоагулянту 3 крові та можливим ризиком кровотеч. За умови перебування на цільових значенннях Міжнародного нормалізованого відношення (МНВ) понад 60\% часу, для безпечної фармакотерапії, пацієнтам призначалися достовірно різні дози варфарину у групах: у групі 3 наявністю дигоксину доза варфарину становила $3,36 \pm 0,28$ мг проти $4,30 \pm 0,21$ мг у групі без дигоксину $(P=0,006)$; у групі з наявною мутацією цитохрому доза $3,08 \pm 0,25$ мг проти 4,15 $\pm 0,22$ у групі пацієнтів без мутації $(P=0,008)$. Крім того, у пацієнтів з генетичним поліморфізмом ензимів детоксикації, спостерігалася достовірно більша кількість кровотеч (легких та клінічно значимих, кровотеч у критичний орган), проте серед цих пацієнтів, кровотечі виникали на рівні МНВ від 2,6 (у разі рекомендованого МНВ європейським товариством кардіологів для пацієнтів із фібриляцією на рівні від 2,0-3,0). Тому пацієнти 3 генетичними мутаціями потребують персоналізованого підходу та контролю МНВ в більш безпечному діапазоні (від 2,0 до 2,5) та врахування взаємодії між лікарськими засобами.

К л ю ч о в і с л о в а: варфарин, генетичний поліморфізм СҮР2С9, повільні метаболізатори, прийом антикоагулянтів, кровотеча.

\section{References}

1. Galli F, Borghi L, Carugo S, Cavicchioli M, Faioni EM, Negroni MS, Vegni E. Atrial fibrillation and psychological factors: a systematic review. PeerJ. 2017; 5: e3537.

2. Sychov OS, Romanova OM. Atrial fibrillation: the state of problems in Ukraine and abroad. Ukr J Cardiol. 2007;(5):63-66. (In Ukrainian).

3. Kirchhof P, Benussi S, Kotecha D, Ahlsson A, Atar D, Casadei B, Castella M, Diener HC, Heidbuchel H, Hendriks J, Hindricks G, Manolis AS, Oldgren J, Popescu BA, Schotten U, Van Putte B, Vardas P, ESC Scientific Document Group. 2016 ESC Guidelines for the management of atrial fibrillation developed in collaboration with EACTS. Eur Heart J. 2016; 37(38): 28932962. 
4. Ma Z, Cheng G, Wang P, Khalighi B, Khalighi K. Clinical model for predicting warfarin sensitivity. Sci Rep. 2019; 9(1): 12856.

5. Jenner KM, Simmons BJ, Delate T, Clark NP, Kurz D, Witt DM. An education program for patient self-management of warfarin. Perm J. 2015; 19(4): 33-38.

6. Christensen TD. Self-management of oral anticoagulation therapy--methodological and clinical aspects. Dan Med Bull. 2011; 58(5): B4284.

7. Karpov YA. Approaches to the therapy of patients with hypertension and atrial fibrillation. Cardiology News. 2013; (4): 2-9. (In Russian).

8. Shulkin AV, Yakusheva EN, Popova NM. The role of P-glycoprotein in rational pharmacotherapy in cardiology. Ration Pharmacother Cardiol. 2013; 9(6): 701-707. (In Russian).

9. Vorobyeva NM, Panchenko EP, Dobrovolsky AB, Titaeva EV, Khasaeva ZB, Konovalova NV, Postnov AYu, Kirienko AI. Polymorphisms of genes CYP2C9 and VKORC1 in patients with venous thromboembolic complications in Moscow population: effects on stability of anticoagulant therapy and frequency of hemorrhage. Ter Arkh. 2011; 83(6): 59-65. (In Russian).

10. Maliarchuk IV, Horovenko NG. The role of intergenic interactions of genes encoding biotransformation enzymes of indirect anticoagulants and genes of the hemostatic system in the selection of a dose of warfarin. $J$ Nat Acad Med Sci Ukraine. 2014; 20(2): 246251. (In Russian).

11. Sychov DA, Ramenskaya GV, Ignatiev IV, Kukes BG. Eds. Kukes VG, Bochkov NP. Clinical pharmacogenetics. M.: GEOTARMedia, 2007. 245 p. (In Russian).

12. Zotova IV, Nikitin AG, Fattakhova EN, Brovkin AN, Khodyrev DS, Lavrikova EY,
Isaeva MY, Kosukhina AS, Nosikov VV, Zateyshchikov DA. The affect of influence of genes' polymorphisms CYP2C9 and VKORC1ON of the safety of the therapy by warfarin. J Clin Pract. 2013;4(4):3-10.

13. Guidelines for cardiology. Ed. V.M. Kovalenko. K.: MORION, 2009. 1257 p. (In Ukrainian).

14. Rebrova OY. Statistical analysis of medical data. Application software package Statistica. M: Medisfera, 2006. 312 p. (In Russian).

15. Sivolob, AV, Rushkovsky SR, Kiryachenko SS. Genetics: a textbook. K.: Publishing and Printing Center "Kyiv University", 2008. 320 p. (In Ukrainian).

16. Zhang F, Finkelstein J. Inconsistency in race and ethnic classification in pharmacogenetics studies and its potential clinical implications. Pharmgenomics Pers Med. 2019;12:107-123.

17. Ma Q, Lu AYH. Pharmacogenetics, pharmacogenomics, and individualized medicine. Pharmacol Rev. 2011; 63(2): 437-459.

18. Sánchez-Diz P, Estany-Gestal A, Aguirre C, Blanco, Carracedo A, Ibáñez L, Passiu M, Provezza L, Ramos-Ruiz R, Ruiz B, SaladoValdivieso I, Velasco EA, Figueiras A. Prevalence of CYP2C9 polymorphisms in the south of Europe. Pharmacogenomics J. 2009; 9(5): 306-310.

19. Xie HG, Prasad HC, Kim RB, Stein CM. CYP2C9 allelic variants: ethnic distribution and functional significance. Adv Drug Deliv Rev. 2002; 54(10): 1257-1270.

20. Dorado P, Sosa-Macias MG, Peñas-Lledó EM, Alanis-Bañuelos RE, Wong ML, Licinio J, Lares-Asseff I, Llerena A. CYP2C9 allele frequency differences between populations of Mexican-Mestizo, Mexican-Tepehuano, and Spaniards. Pharmacogenomics J. 2011; 11(2): 108-112. 